\title{
MEASURING THE EFFICIENCY OF LISTED HOUSING SECTOR COMPANIES USING THE DATA ENVELOPMENT APPROACH IN INDIA
}

\author{
Bhawna Malhotra ${ }^{1}$ and Neelam Dhanda ${ }^{2}$ \\ ${ }^{1}$ Kurukshetra University, India \\ E-mail: mbhawna9@gmail.com \\ ${ }^{2}$ Kurukshetra University, India \\ E-mail:ndhanda@kuk.ac.in
}

\begin{abstract}
The purpose of this study was to assess the technical efficiency and productivity of listed Housing sector companies in India, from 2008 to 2017. The study employed the Data Envelopment Approach (DEA) to examine the efficiency of the selected sample. The Malmquist Productivity Index was used to reveal the productivity change in Housing companies over the specified time. The study found little productivity growth among the Decision Making Units (DMUs) in spite of their efficiency improvement practices during the study period. The study indicates that there is a need for better utilization of resources and scale expansion. Further improvements in the housing sector can be achieved by technological improvements as it is the main reason behind poor productivity growth during the study period.
\end{abstract}

Keywords: DEA, Malmquist Index, housing sector, technical efficiency, total factor productivity

$\underline{\text { ARTICLE INFO }}$

Article History:

Received: 24 October 2019

Accepted: 27 January 2020

Published: 30 April 2020 


\section{INTRODUCTION}

In the past the concept "Housing" was associated with a physical phenomenon, and the policies of countries for its provision are mostly related with construction costs that may largely vary depending on the type of construction material, various housing standards and construction quality (Grimes \& Orville, 1976). Swami Dr. Tathagat Bharti ${ }^{1}$, in his autobiography, stated that 'Housing is a basic need that provides a place of 'home' to the individual and is valuable collateral that can enable him to access credit from the financial market. It is also a place of worship'. Investment inflows in the housing sector up till 2014 have been Rs. 590 billion i.e., 47 per cent of the total money invested in real estate. The contribution of the residential sector to the Gross Domestic Product (GDP) would almost double to 11 per cent by 2020 (The Economic Times Wealth, 2018).

This study used the Data Envelopment Analysis (DEA), a nonparametric statistical technique to evaluate the productivity of the Indian housing sector companies for the period 2008 to 2017. DEA is a technique that tests whether decision making units (DMUs) are operating at their efficient frontier or not (Anderson et al., 2004).

\section{GROWTH OF THE HOUSING SECTOR IN INDIA}

The Housing sector in India has experienced a rapid growth in the past few years. According to a joint report by CREDAI and $\mathrm{JLL}^{2}$, India's real estate sector is projected to reach $\$ 180$ billion by 2020 from $\$ 126$ billion in 2015 . Regulatory reforms, steady demand generated through rapid urbanisation, rising household income and the emergence of affordable and nuclear housing are some of the key drivers of growth of the sector.

The Real Estate Regulatory Authority (RERA) is expected to consolidate the Indian Real Estate industry with the elimination of unscrupulous developers. Sales figures are expected to improve with RERA. The recent relaxation in Foreign Direct Investment (FDI) has provided a

1 Autobiography of Swami Dr. Tathagat Bharti, SS Publication, Bhopal, 1991 edition

2 "Traversing through the epic predicting the curve" joint report by CREDAI (Confederation of Real Estate Developer's Association of India) and JLL (Jones Lang Lasalle) Property Consultant private limited. 
huge boost to investment in the industry. RERA and the Goods and Services Tax (GST) have created a strong base for the sector to grow, which coupled with India's strong economic advancement have provided a boost to this sector.

Also, the Government's Credit Linked Subsidy Scheme (CLSS) has many takers, making affordable housing a hot selling segment across metros and Tier II cities ${ }^{3}$. In order to push the mission 'Housing for All' by 2022 and to increase demand in the Middle Income Group (MIG) category, the government has extended the CLSS scheme to March 2019 and further relaxed the carpet area norms for the MIG category I to 120 square metres under the CLSS scheme from its existing 90 square metres and for category II, from 110 to 150 square metres (Source: Ministry of Housing and Urban Affairs, India).

The Hong Kong based brokerage firm Credit Lyonnais Securities Asia (CLSA) said the housing cycle in India has started showing some green shots. This can be gauged from the cement demand, developers' pre sales and the Government's affordable housing programme. The brokerage house believed that the Pradhan Mantri Awas Yojana (PMAY) urban programme is shifting from the announcement to the execution mode for nearly 2 million houses, significant budget raises and recent order wins by large contractors.

The response of developers to create affordable housing supply has started gaining some momentum with announcements of affordable targeted coin vestment platforms being created by leading developers. A combination of improved affordability and government support drove the housing cycle improvement through 2018.

The objective of this study was to analyse the technical efficiency and performance of Listed Housing companies in India by applying the DEA approach. The study also used the Malmquist Index to determine the contribution of technical efficiency change and technological change to the total factor productivity growth of the selected companies.

3 Tier II cities are smaller cities as compared to metropolitan cities statistically having population around one million. 


\section{REVIEW OF LITERATURE}

The Indian Housing sector has witnessed instability from the past few years. Declining sales and increasing debt affected the industry, which is considered as the growth engine of the economy. The sector saw a sharp decline in the demand due to high interest rates, higher prices and cautious buyer sentiments.

Developers also reduced the supply in response to the decreasing demand. While the buyers practiced caution, the developers did not pause which leds to an increased gap between demand and supply. However, it does not mean that all the companies underperformed during this period. The present study made an attempt to distinguish the performers from the non-performers by using the Data Envelopment Analysis (DEA).

Charnes et al. (1978) introduced the DEA, which is based on Farrel (1957). The DEA measures the relative performance of decision making units (DMUs). Zheng, Chau and Hui (2011) used the DEA approach to evaluate the performance and efficiency of 94 real estate companies listed on the Chinese stock markets for the period 2009. The study concluded three outcomes. The conclusions of the study indicated that the average overall efficiency (O.E.), pure technical efficiency (P.T.E) and scale efficiency (S.E.) of Listed Real Estate Companies (L.R.E.C.) were 0.78, 0.84 and 0.92 respectively. The research also found that 69 per cent of inefficient L.R.E.C's were dominated by increasing returns to scale, suggesting that these companies could further increase their operating efficiency through scale expansion.

Sepehrdoust (2011) analysed the performance of the housing Industry in Iran for the period 2006-09, using the DEA and Regression analysis. Using data from 30 states, the study found that only 37 per cent of states operated efficiently technically and that average efficiency score was 0.94 . The study suggested that subsidy should be provided to disadvantaged states to improve efficiencies in the sector and to solve the current housing problem in Iran. Chiu and Wang (2011) proposed an evaluation model to determine the financial performance of 27 construction companies listed in Taiwan for the period 1999 to 2008. The study used the SWOT analysis to determine the Input and Output indicators and Canonical Correlation 
Analysis (CCA) to reduce the original indicators to generate potential indicators and standardized the potential indicators to obtain largest correlation between all indicators. Then in the last step, the DEA was used to calculate the efficiency values and sort the financial performance. The model compared efficiency for the short term, medium term and long term periods. During the short term, 5 DMU's operated at the efficient frontier, 7 in the medium term and 15 in the long term. The findings revealed that the model effectively assessed the performance of construction companies.

Soetants and Fun (2014) evaluated the performance of property and real estate companies listed in the Indonesia Stock Exchange using the DEA method. The sample consisted of 23 companies from the period 2009 to 2012. The model consisted of 3 inputs (operating expense, fixed assets and inventories \& land for development) and 1 output (Net Income). The study concluded that companies operating under constant returns to scale increased from 17.39 per cent to 39.13 per cent during the study period while inefficient companies had decreasing returns to scale. The main cause of inefficiency from 2009-11 was scale inefficiency while in 2012, there was pure technical inefficiency.

Roy and Kohli (2016) measured technical efficiency of 15 real estate companies in India, using the DEA. Using data from the Capitaline database for the years 2012-15, the study found that the inefficiency in the sector was due to both pure technical inefficiency and scale inefficiency. The study also found that after 2013, there was a sharp decline in the growth of the real estate sector. However, 5 firms remained efficient throughout the study period. Turnover inventory and excess manufacturing expenses were the main areas of inefficiency in the Indian real estate sector.

Ahmed and Mohamad (2016) used the DEA to assess the performance of Real Estate Investment Trust (REITs) in Singapore for the years 20092013. The study found that 9 REITs operated at the efficient frontier in 2009 and seven each in remaining years. The researchers used the Malmquist Productivity Index to evaluate productivity change of the REITs. The findings of the study revealed that inspite of efficiency improvements among REITs, they experienced little productivity growth at the frontier. With respect to productivity change, most REITs suffered from technological regress, suggesting that they should improve technological efficiency. 
Chen and $\mathrm{Li}$ (2017) evaluated the operating efficiency of 30 real estate companies listed in the Shenzhen and Shanghai markets for the period 2009 to 2015. The author used the Charnes, Cooper and Rhodes (CCR) and the Banker, Charnes and Cooper (BCC) ${ }^{4}$ models for data envelopment analysis to analyse the efficiency of real estate companies. Further, the Tobit regression model was used to study the influence the different factors on efficiency. The study concluded that there was low efficiency among most of the companies and there was wide efficiency gap. The Tobit regression model showed a positive correlation of efficiency with net interest rate and education level; however it showed a negative correlation with asset liability ratio. The study suggested that the real estate companies should construct a scientific financial and performance appraisal index system, so that the funds can be improved. The study also suggested that the sector should instead use minimum bank loans so that they can issue bonds or establish financial sources in order to expand financial efficiency of a company.

From the literature review, it is evident that some studies have been conducted on the efficiency of the housing sector across the world. To the author's knowledge, the housing sector has been scarcely investigated from the point of view of efficiency and productivity in the Indian context. Therefore, this study can immensely contribute to the literature by providing information regarding the efficiency and productivity of the Indian housing sector in general.

\section{DATA AND RESEARCH METHODOLOGY}

\section{Sources of Data}

The information relating to the financial variables used in the study was collected from the CAPITALINE Database. The CAPITALINE database is a product of Capital market, India's foremost investment fortnightly. It is the most reliable and powerful online database providing financial and other information of Indian listed and unlisted companies through paid subscription. Built up since 1985, having special expertise in data collection,

4 CCR (Charnes, Cooper and Rhodes) model used CRS (Constant Returns to Scale) Approach BCC (Banker, Charnes and Cooper ) model used VRS ( Variable Returns to Scale) Approach 
standardisation and presentation, it has gained the highest level of trust and respect in the financial information industry.

\section{Sample Selection}

The sample selection consisted of housing sector companies listed on the Bombay Stock Exchange (BSE) from 2008-2017. Inactive firms with regard to business operations and companies having missing values were excluded from the list. The sample was selected on the basis of total assets on $31^{\text {st }}$ March 2017. The sample included those companies whose total assets were more than ten billion. Two inputs and three outputs are used to analyse the data over a period of ten years. Inputs and outputs were selected on the basis of previous studies. The inputs utilized were total expenditure and fixed assets. The three outputs are return on equity, total income and gross profit. The sample included following companies:

Table 1: Profile of Selected Companies

\begin{tabular}{lcc}
\multicolumn{1}{c}{ Company Name } & $\begin{array}{c}\text { Year of } \\
\text { Incorporation }\end{array}$ & $\begin{array}{c}\text { Total Assets as on } \\
\text { 31 } \\
\text { (in Billion) }\end{array}$ \\
\hline DLF Ltd. & 1963 & 248.01 \\
Housing Development \& Infrastructure Ltd. & 1996 & 133.06 \\
Unitech Ltd. & 1971 & 114.69 \\
Sobha Ltd. & 1995 & 47.13 \\
Parsvnath Developers Ltd. & 1990 & 43.47 \\
Peninsula Land & 1871 & 38.13 \\
Ansal Properties \& Infrastructure Ltd. & 1967 & 23.99 \\
Marg & 1994 & 16.53 \\
D S Kulkarni Developers Ltd. & 1991 & 12.69 \\
Ganesh Housing Corporation Ltd. & 1991 & 11.14 \\
Ansal Housing \& Construction Ltd. & 1983 & 10.39 \\
Vipul Ltd. & 1991 & 10.07 \\
\hline
\end{tabular}

Notes: This table shows descriptions of the firms in the sample, including name, year of incorporation and total assets as on 31st March, 2017 


\section{Methodology}

This paper adopted the Data Envelopment Analysis (DEA) model to examine the efficiency of Housing sector in India. The DEA, initially introduced by Charnes et al. (1978), is a non- parametric method for evaluating the relative efficiency of decision making units (DMUs) with multiple inputs and outputs. It uses a linear programming technique to construct an efficient frontier and determines deviations of each DMU from that frontier. These deviations from the efficient frontier signify performance inefficiencies that are a function of the failure to minimize inputs and maximize outputs (Douglas, 2006).

Technical efficiency exists when a DMU cannot reduce its input usage without decreasing its output. The DEA estimates the Overall Technical Efficiency (OTE) which helps to determine inefficiency due to the input/ output configuration and as well as size of operation. Technical efficiency can be decomposed into pure technical efficiency (PTE) and scale efficiency (SE) measures. Technical efficiency (constant returns to scale-TECRS) is the product of pure technical efficiency (variable returns to scale efficiencyPTEVRS) and SE:

$$
\mathrm{TE}_{\mathrm{CRS}}=\mathrm{PTE}_{\mathrm{VRS}} \times \mathrm{SE}
$$

Pure technical efficiency (PTE) reflects the way in which production unit resources are managed. Scale efficiency (SE) determines whether the production unit operates at an optimal scale or not. A value of unity implies that the firm is on the industry frontier in the relevant year, whereas value less than unity implies that the firm is below the frontier or, in other words, technically inefficient. Thus, the further the value is from unity, the more inefficient the firm is.

In DEA technical efficiency can be defined through two perspectives. First is input oriented TE that aims to reduce the inputs to achieve the desired output and the second one aims to increase the output for a given set of inputs. The present study used the output oriented approach. 


\section{Malmquist Index}

The Malmquist Index was applied in this paper for the purpose of analysing the contributions of technical and efficiency changes to productivity increases in the units. Fare et al. (1994) defined productivity growth as the product of efficiency changes and technical changes. The concept of the Malmquist index was first proposed by Malmquist (1953) and then further studied and developed by several authors (Caves, Christensen, \& Diewert, 1982; Fare \& Grosskopf, 1992; Fare, Grosskopf, Lindgren, \& Roos, 1989, 1994; Fare, Grosskopf, \& Russell, 1998; Thrall, 2000). The Malmquist Productivity Index (MPI) comprises of distance functions signifying multiple input and output technologies based on the input and output quantities. The output distance function is used to deal with maximal proportional increase of the output, given the inputs. The MPI computes the Total Factor Productivity (TFP) growth change between two data points by assessing the ratio of the distances of each data point relative to a common technology. The MPI shows the increase or decrease in efficiency with up gradation or degradation of the frontier technology over time. The TFP index can be decomposed into technical efficiency change and technological change.

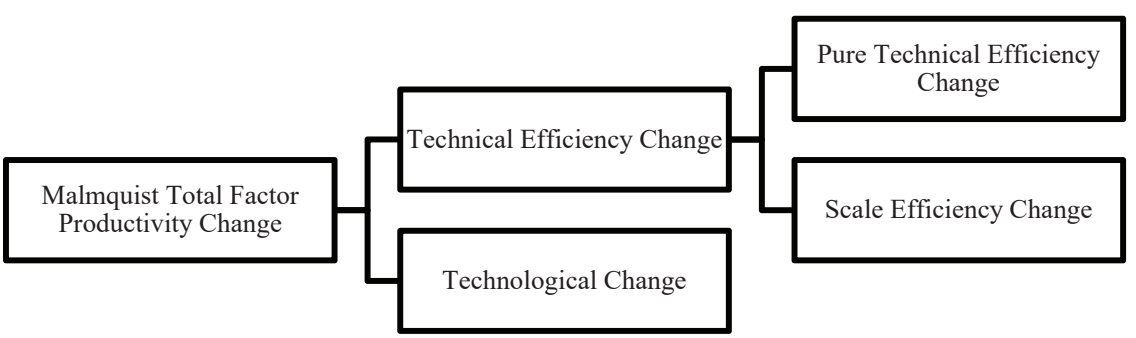

Figure 1: Components of Malmquist Productivity Change

\section{DATA ANALYSIS AND FINDINGS}

Table 2 shows the descriptive analysis of Inputs and Outputs used in the study to evaluate the efficiency of listed housing sector companies in India. Three outputs and two inputs were used in the study. Output consists of Return on Equity, Total Income and Gross profit, whereas input includes Total expenditure and Fixed Assets. The Outputs and Inputs were selected on the basis of previous studies. 
Table 2: Descriptive Analysis (2008-2017)

\begin{tabular}{|c|c|c|c|c|c|c|}
\hline \multirow[b]{2}{*}{ Year } & \multirow{2}{*}{$\begin{array}{c}\text { Descriptive } \\
\text { Statistics }\end{array}$} & \multicolumn{3}{|c|}{ Outputs } & \multicolumn{2}{|c|}{ Inputs } \\
\hline & & $\begin{array}{l}\text { Return on } \\
\text { Equity }\end{array}$ & $\begin{array}{c}\text { Total } \\
\text { Income }\end{array}$ & $\begin{array}{l}\text { Gross } \\
\text { Profit }\end{array}$ & $\begin{array}{c}\text { Total } \\
\text { Expenditure }\end{array}$ & $\begin{array}{l}\text { Fixed } \\
\text { Assets }\end{array}$ \\
\hline \multirow[t]{3}{*}{2008} & Mean & 32.53 & 1848.03 & 651.19 & 1099.11 & 191.68 \\
\hline & Median & 27.00 & 628.80 & 192.46 & 463.19 & 74.39 \\
\hline & S.D. & 15.91 & 2246.24 & 945.32 & 1358.37 & 407.79 \\
\hline \multirow[t]{3}{*}{2009} & Mean & 11.41 & 1260.64 & 378.81 & 672.88 & 220.80 \\
\hline & Median & 11.04 & 743.20 & 121.32 & 607.02 & 82.94 \\
\hline & S.D. & 7.23 & 1225.13 & 579.28 & 476.67 & 504.89 \\
\hline \multirow[t]{3}{*}{2010} & Mean & 9.76 & 1168.85 & 299.35 & 696.05 & 216.72 \\
\hline & Median & 9.24 & 816.33 & 155.00 & 605.00 & 84.04 \\
\hline & S.D. & 7.14 & 1103.75 & 349.10 & 547.90 & 478.92 \\
\hline \multirow[t]{3}{*}{2011} & Mean & 8.70 & 1406.67 & 382.09 & 792.51 & 227.82 \\
\hline & Median & 9.46 & 955.41 & 121.04 & 683.64 & 104.12 \\
\hline & S.D. & 4.02 & 1466.64 & 520.01 & 736.99 & 480.02 \\
\hline \multirow[t]{3}{*}{2012} & Mean & 5.82 & 1272.66 & 299.21 & 713.28 & 259.54 \\
\hline & Median & 5.43 & 1010.31 & 165.29 & 637.79 & 86.32 \\
\hline & S.D. & 3.37 & 1217.19 & 451.82 & 496.59 & 543.73 \\
\hline \multirow[t]{3}{*}{2013} & Mean & 3.86 & 1073.90 & 177.92 & 623.86 & 266.05 \\
\hline & Median & 3.69 & 854.48 & 108.16 & 627.22 & 90.03 \\
\hline & S.D. & 6.76 & 911.77 & 233.81 & 412.32 & 560.65 \\
\hline \multirow[t]{3}{*}{2014} & Mean & -0.25 & 1160.31 & 122.06 & 774.80 & 231.02 \\
\hline & Median & 2.49 & 793.96 & 57.43 & 505.48 & 91.21 \\
\hline & S.D. & 15.19 & 1145.82 & 209.71 & 675.95 & 440.37 \\
\hline \multirow[t]{3}{*}{2015} & Mean & 3.67 & 1107.65 & 140.18 & 731.77 & 233.58 \\
\hline & Median & 2.73 & 795.02 & 32.36 & 715.13 & 108.96 \\
\hline & S.D. & 4.80 & 1184.21 & 396.60 & 603.83 & 439.58 \\
\hline \multirow[t]{3}{*}{2016} & Mean & 2.32 & 1156.68 & 187.31 & 750.50 & 178.25 \\
\hline & Median & 2.30 & 534.90 & 30.48 & 426.15 & 92.90 \\
\hline & S.D. & 2.87 & 1506.18 & 537.57 & 750.24 & 194.15 \\
\hline \multirow[t]{3}{*}{2017} & Mean & 0.68 & 1036.80 & 97.32 & 731.28 & 145.95 \\
\hline & Median & 0.56 & 447.27 & 12.41 & 391.85 & 97.01 \\
\hline & S.D. & 3.80 & 1320.71 & 311.29 & 812.45 & 149.73 \\
\hline
\end{tabular}

Note: This table presents the descriptive statistics for each input and output variable during the study period from 2008 to 2017

Based on the DEA analysis, the number of efficient firms in the sample for each year is shown in Table 3.

In 2008, 5 firms were 100 per cent efficient $(E k=1)$, whereas the other 7 firms showed an efficiency score less than 100 per cent $(E k<1)$. Whenever the relative efficiency indicator is equal to 100 per cent, it indicates that the unit optimally utilized all the inputs to produce the given outputs. 
Six firms had 100 per cent efficiency during 2009 and 2010, whereas in 2011, 5 firms showed 100 per cent efficiency. Out of total number of DMUs i.e., 12, the number of efficient firms varied from year to year but it was the maximum in 2015 i.e., 8 firms, while others remained less efficient. For example, Sobha Ltd. had an efficiency of 0.742 in 2015, indicating that the firm utilized 25.8 per cent excess inputs.

During the study period DLF, HDIL, UNITECH and VIPUL were consistently efficient under the Variable Returns to Scale (VRS) but not under the Constant Returns to Scale (CRS) because of scale inefficiencies, however Ganesh Housing was consistently efficient, both under the CRS and VRS. HDIL was technically efficient for all years except for 2011 and 2013 due to reduced SE during those years. Peninsula land was consistently efficient in both CRS and VRS up to 2013 except in 2008, after then it showed inefficiency both due to inefficiencies in VRS and scale.

Table 3: Efficient Firms in Sample

\begin{tabular}{ccc}
\hline Year & Total no. of DMUs & No. of efficient firms $\left(\mathrm{TE}_{\mathrm{CRS}}\right)$ \\
\hline 2017 & 12 & 5 \\
2016 & 12 & 7 \\
2015 & 12 & 8 \\
2014 & 12 & 4 \\
2013 & 12 & 6 \\
2012 & 12 & 7 \\
2011 & 12 & 5 \\
2010 & 12 & 6 \\
2009 & 12 & 6 \\
2008 & 12 & 5 \\
\hline
\end{tabular}

Notes: This table summarizes the total number of efficient firms that were found to be technically efficient based on the DEA, in comparison to the total number of firms.

Table 4 presents the individual technical efficiency estimates (TECRS) and its components, the pure technical efficiency (PTECRS) and SE estimates for 12 housing firms in the sample.

The efficiency estimates are discussed in more detail here so as to identify the components that contribute to relative efficiency. In 2017, 
DLF Ltd., HDIL, DS Kulkarni, Ganesh Housing and Vipul were technically efficient. On the other hand, Parsvnath, Peninland and ANSALHSG were inefficient. Sobha, Ansalapi and Marg were only efficient for VRS, which indicated that the technical inefficiency of these units was due to scale inefficiencies.

In 2016, Dlf Ltd., Hdil, Unitech, Ansalapi, Ds Kulkarni, Ganesh Housing and Vipul were technically efficient. Unitech and Ansal properties were not efficient in 2017. Marg was efficient only in terms of VRS, which means that its technical inefficiency was because of scale inefficiency. The remaining units were inefficient in 2016 in terms of CRS owing to inefficiency in both pure technical and scale efficiency.

In 2015, Dlf Ltd., Hdil, Unitech, Parsvnath, Ds Kulkarni, Ganesh Housing, Ansal housing and Vipul were technically efficient. Sobha was efficient in terms of VRS but not in terms of SE. The remaining units were not efficient due to both pure technical inefficiencies and scale inefficiencies. The least inefficient unit was Marg.

In 2014, HDIL, Marg and Ganesh Housing were technically efficient. Sobha and Vipul were efficient only in terms of VRS. It means that these units had efficient input utilization but their technical efficiency declined due to failure to operate at CRS. The remaining DMUs were inefficient due to both input utilization and failure to achieve CRS. 


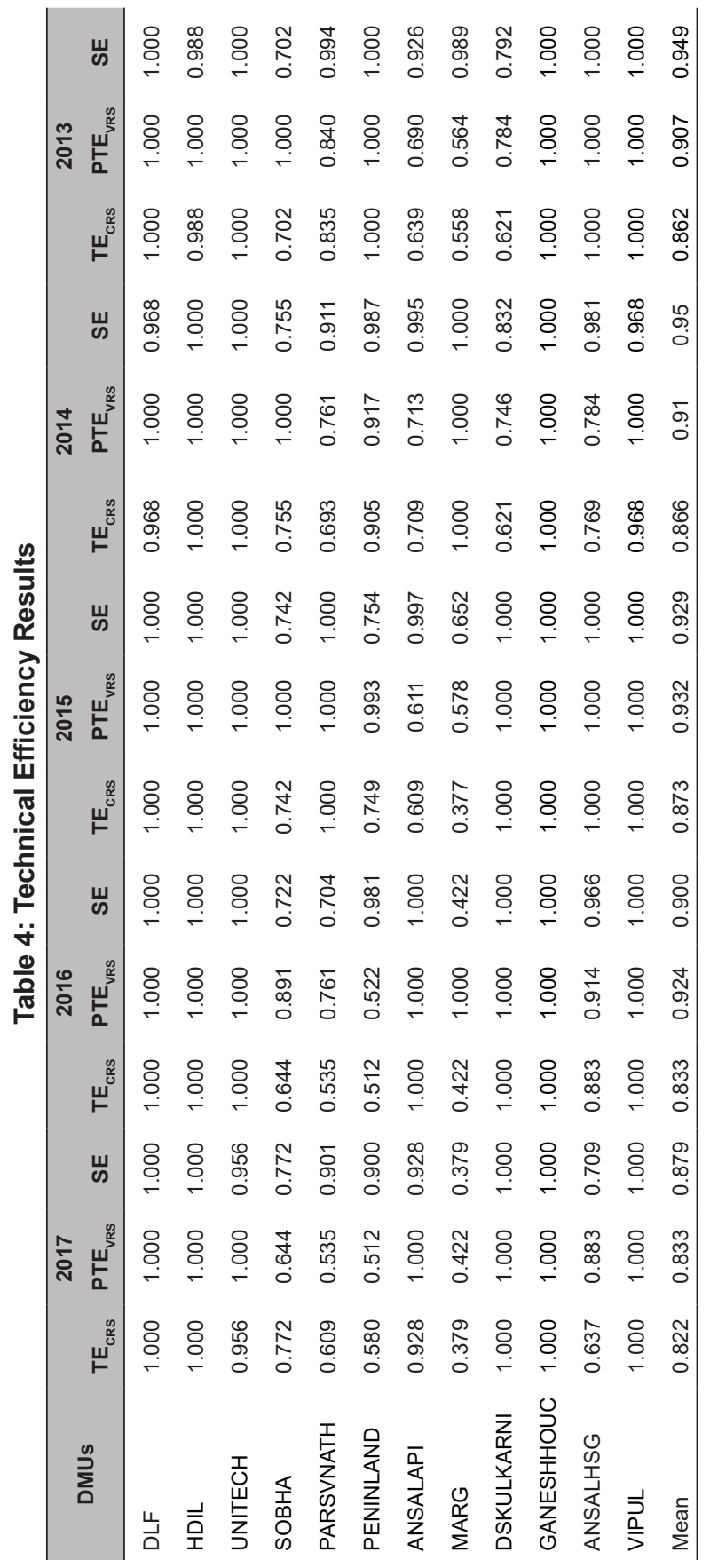




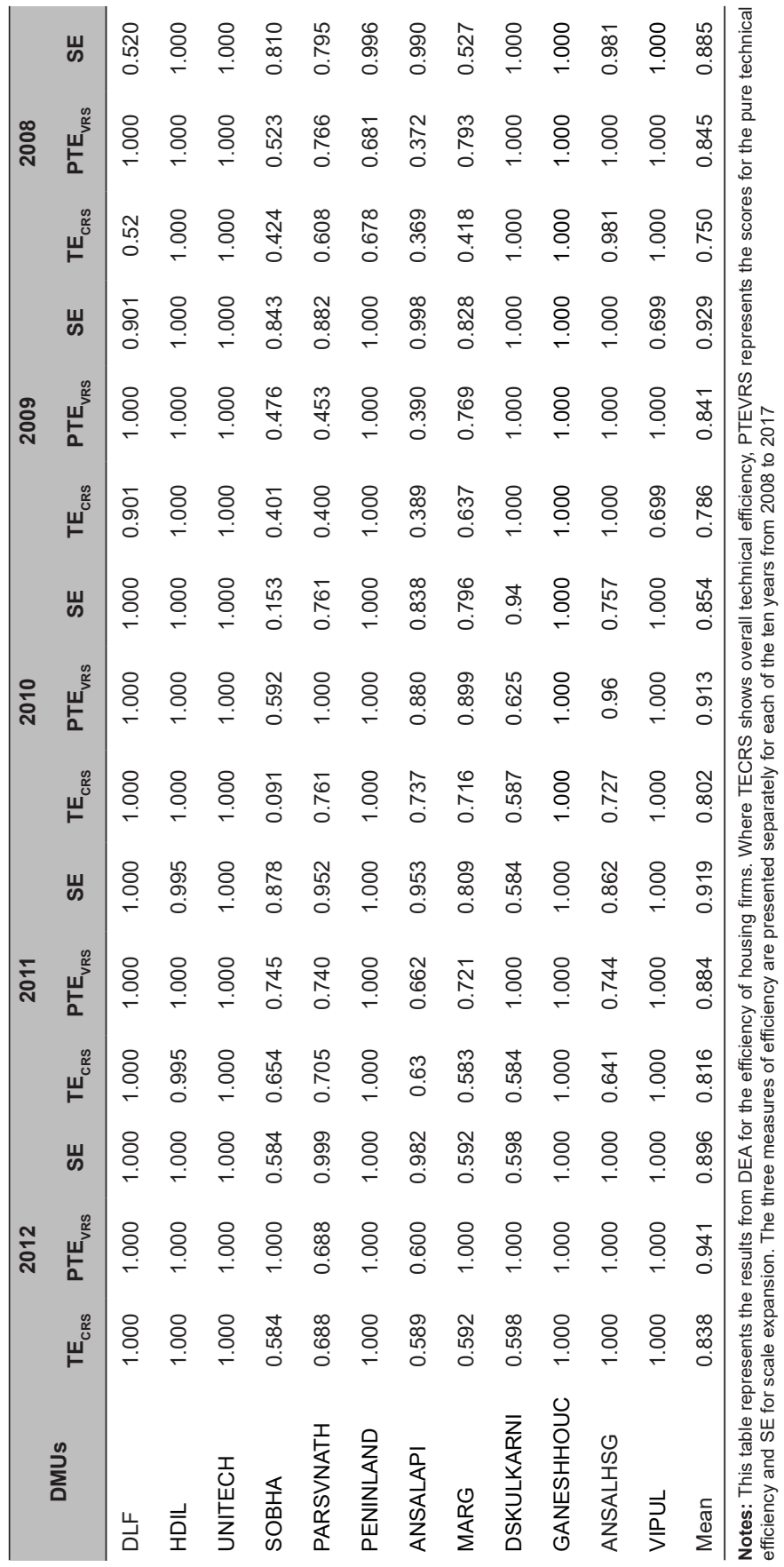


In 2013, DLF, Unitech, Peninsula Land, Ganesh Housing, Ansal Housing and Vipul were technically efficient. HDIL and Sobha were efficient only in terms of VRS. The other firms had inefficient efficiencies which were attributable to both pure technical inefficiency and scale inefficiency.

In 2012, DLF, HDIL, Unitech, Peninsula Land, Ganesh Housing, Ansal Housing and Vipul were technically efficient. Sobha, Marg and DS Kulkarni were efficient only in terms of VRS; it means that their technical inefficiency was because of scale inefficiencies. Parsvnath and Ansal Properties were inefficient.

In 2011, DLF, Unitech, Peninsula Land, Ganesh Housing and Vipul were efficient. HDIL and DS Kulkarni were efficient only in terms of VRS. The remaining units were inefficient due to both scale inefficiencies and pure technical inefficiency. In 2010, DLF, HDIL, Unitech, Peninsula Land, Ganesh Housing and Vipul were efficient. Parsvnath was efficient in terms of VRS only, however rest of the units suffered from both pure technical inefficiency and scale inefficiencies.

In 2009, HDIL, Unitech, Peninsula Land, DS Kulkarni, Ganesh Housing and Ansal Housing were efficient. DLF and Vipul were efficient only in terms of VRS. The remaining units were inefficient.In 2008, HDIL, Unitech, DS Kulkarni, Ganesh Housing and Vipul were technically efficient. DLF and Ansal Housing were efficient only in VRS. The remaining units were all inefficient.

Parsvnath and Ansal Housing were efficient in 2015; they were inefficient in both 2016 and 2017 due to both scale inefficiencies and pure technical inefficiency. Unitech was consistently efficient upto 2016; it was inefficient in 2017 due to scale inefficiency. It remained efficient in terms of VRS in 2017, indicating that it still had efficient input utilization but suffered from scale inefficiency. To further analyse the performance of Housing companies in terms of productivity growth, the Malmquist index was conducted.

Table 5 presents the individual change estimates for the DMUs and their contributing components in detail for each period. Three firms (Sobha, Ganesh Housing and Vipul) showed a positive total factor productivity 
changes from 2016 to 2017 . For Sobha, the improvement in productivity was due to improvement in performance of technical efficiency, which resulted from improvement in both scale efficiency and input utilization. Sobha showed a slight technological deterioration. However, Ganesh Housing and Vipul showed technological improvements, which caused an equivalent productivity growth, whereas their technical efficiency remained the same.

On the other hand, DLF, HDIL and DS Kulkarni remained same on technical efficiency but declined in productivity because of technological deterioration. From 2015 to 2016, 6 firms showed improved performance. This improvement in productivity was mostly because of technological change. All the 6 firms saw technological improvement although technical efficiency of 4 firms (DLF, Unitech, Ganesh Housing and Vipul) remained same. Sobha, Parsvnath, Peninsula Land and Ansal Housing saw deterioration in both technical efficiency and technological change leading to productivity regress. However HDIL remained the same on both the technical efficiency and technological improvement, resulting in no change in overall productivity.

During 2014 to 2015, 5 firms (DLF, HDIL, Sobha, Parsvnath and Marg) showed positive total factor productivity change. This can be attributed directly to technological change as 3 firms out of 5 experienced improvements in this component. While other two showed slight technological deterioration. Five firms (HDIL, Unitech, Ganesh Housing, Ansal Housing and Vipul) remained same on technical efficiency, which came from no change in input utilization and SE. 


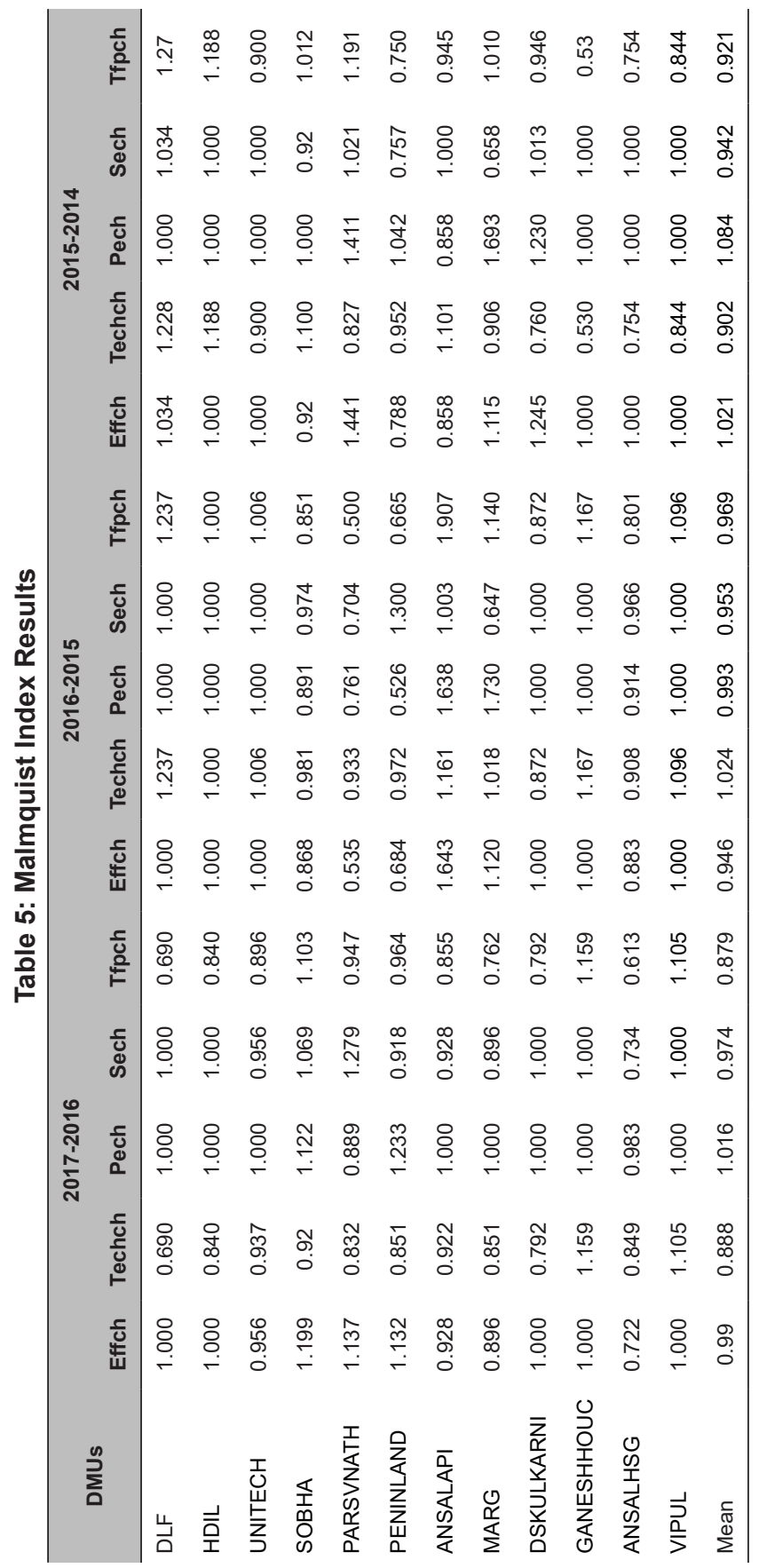




\begin{tabular}{|c|c|c|c|c|c|c|c|c|c|c|c|c|c|}
\hline $\begin{array}{l}\text { 은 } \\
\text { 은 }\end{array}$ & $\begin{array}{l}\widehat{c} \\
\infty \\
\infty \\
0\end{array}$ & $\stackrel{\text { ọ }}{\circ}$ & $\begin{array}{l}\mathscr{0} \\
\stackrel{0}{\circ} \\
0\end{array}$ & $\begin{array}{l}\stackrel{8}{\infty} \\
0 \\
0\end{array}$ & 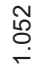 & $\hat{o}$ & চ. & $\begin{array}{l}\mathscr{0} \\
\stackrel{0}{0} \\
0\end{array}$ & $\begin{array}{l}m \\
0 \\
0\end{array}$ & $\begin{array}{l}\text { N్ } \\
\text { ర్ }\end{array}$ & ๙ু & $\begin{array}{l}\text { : } \\
\text { : }\end{array}$ & $\begin{array}{l}m \\
\stackrel{m}{\infty} \\
0 \\
0\end{array}$ \\
\hline 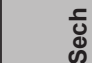 & ঃ & Lొరి & ¿ & \& & \& & ¿ & $\bar{\varnothing}$ & 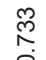 & $\underset{\circlearrowright}{\stackrel{\Delta}{~}}$ & ঃ & $\stackrel{8}{\circ}$ & ৪ & ণै \\
\hline 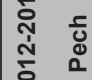 & ঃి & ৪ & ه্ & $\stackrel{\text { m }}{\text { ma }}$ & $\begin{array}{l}\text { Oু } \\
\text { Oे }\end{array}$ & \& & 今̊ & $\begin{array}{l}\infty \\
\stackrel{\infty}{\infty} \\
\stackrel{\sim}{\sim}\end{array}$ & ঃ & ষ্ণ & $\stackrel{\text { f? }}{\sim}$ & 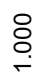 & 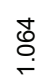 \\
\hline $\begin{array}{l}\frac{5}{0} \\
\frac{5}{0} \\
\stackrel{0}{0}\end{array}$ & $\begin{array}{l}\widehat{c} \\
\infty \\
\infty \\
0 \\
0\end{array}$ & $\begin{array}{l}\infty \\
\stackrel{\infty}{\circ} \\
\stackrel{-}{-}\end{array}$ & $\begin{array}{l}\mathscr{0} \\
\stackrel{\circ}{\circ} \\
0 \\
0\end{array}$ & 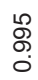 & 足 & గo. & 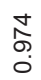 & ồ & $\stackrel{m}{\stackrel{m}{T}}$ & $\begin{array}{l}\text { กิ } \\
\text { ก. }\end{array}$ & 菖 & 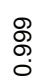 & $\begin{array}{l}\mathscr{L}_{0} \\
\infty \\
0 \\
0\end{array}$ \\
\hline 岳 & ষ্ণ & $\stackrel{\text { L̊ }}{\circ}$ & 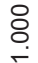 & 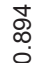 & $\begin{array}{l}\frac{1}{2} \\
\text { o. } \\
0\end{array}$ & ¿ & 芯 & $\underset{\sigma}{\sigma}$ & 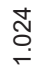 & $\stackrel{\circ}{\circ}$ & 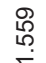 & ৪ & ্ָণ \\
\hline $\begin{array}{l}\text { 응 } \\
\text { 윤 }\end{array}$ & $\bar{\sigma}_{\dot{\sigma}}$ & 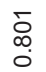 & 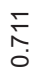 & $\begin{array}{l}\stackrel{2}{\circ} \\
\stackrel{\circ}{\circ}\end{array}$ & 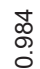 & స̃ & $\begin{array}{l}\mathscr{~} \\
\text { : } \\
\circ\end{array}$ & $\begin{array}{l}\underset{N}{N} \\
\infty \\
0\end{array}$ & $\begin{array}{l}\text { ڤి } \\
\text { م. } \\
0\end{array}$ & 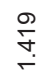 & $\begin{array}{l}\stackrel{1}{\infty} \\
\infty \\
0\end{array}$ & $\begin{array}{l}\text { ఝै } \\
\infty \\
0\end{array}$ & న్రా \\
\hline $\begin{array}{l}\frac{5}{0} \\
\stackrel{\Xi}{\infty}\end{array}$ & ¿্র & 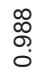 & $\underset{-}{\circ}$ & 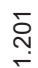 & 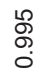 & 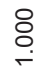 & 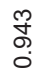 & $\stackrel{\widehat{\omega}}{r}$ & $\underset{\sim}{\stackrel{\sim}{\sim}}$ & $\stackrel{8}{\circ}$ & ৪ & 옴 & $\stackrel{\infty}{\stackrel{\infty}{\circ}}$ \\
\hline 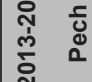 & $\stackrel{8}{\circ}$ & 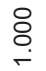 & 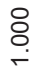 & ه্ & $\stackrel{\text { N̦}}{\sim}$ & $\stackrel{\text { ¿ }}{-}$ & $\stackrel{\circ}{\stackrel{\circ}{\circ}}$ & 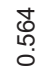 & 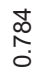 & ৪̊ㅜ & $\stackrel{8}{\circ}$ & ৪̊ㅜㅁ & চ্. \\
\hline 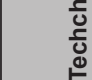 & $\stackrel{\bar{\alpha}}{-}$ & $\begin{array}{l}0 \\
\infty \\
0 \\
0\end{array}$ & \begin{tabular}{l}
$\Sigma$ \\
\multirow{\Lambda}{0}{} \\
0
\end{tabular} & $\begin{array}{c}\text { 尺े } \\
\infty \\
0 \\
0\end{array}$ & $\underset{\infty}{\mp}$ & స్ & ळo & $\begin{array}{l}m \\
\infty \\
0 \\
0\end{array}$ & 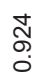 & 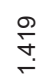 & $\begin{array}{l}\stackrel{L}{\infty} \\
\infty \\
0\end{array}$ & $\begin{array}{l}\widetilde{O} \\
0 \\
0 \\
0\end{array}$ & $\begin{array}{l}\hat{D} \\
\infty \\
0 \\
0\end{array}$ \\
\hline $\begin{array}{l}\text { ज } \\
\text { 离 }\end{array}$ & \&. & $\begin{array}{l}\infty \\
\infty \\
o \\
0 \\
0\end{array}$ & 움 & 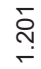 & 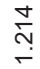 & 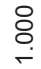 & 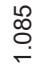 & \begin{tabular}{l}
\multirow{F}{*}{} \\
S
\end{tabular} & $\stackrel{\infty}{\infty}$ & \&̊ & \&̊ㅜ․ & $\stackrel{\circ}{\circ}$ & 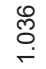 \\
\hline $\begin{array}{l}\frac{5}{0} \\
\text { 윤 }\end{array}$ & $\begin{array}{l}\hat{\alpha} \\
\stackrel{0}{0}\end{array}$ & $\stackrel{\stackrel{2}{\circ}}{\stackrel{\circ}{\leftarrow}}$ & 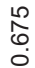 & 음 & $\stackrel{\infty}{\circ}$ & 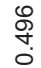 & $\begin{array}{l}\text { \& } \\
\stackrel{\sigma}{\circ}\end{array}$ & $\begin{array}{l}\overline{\hat{\theta}} \\
0 \\
0\end{array}$ & 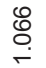 & $\begin{array}{l}m \\
0 \\
0 \\
0\end{array}$ & $\begin{array}{l}\hat{o} \\
\hat{0}\end{array}$ & $\begin{array}{l}\text { oे } \\
0 \\
0\end{array}$ & $\begin{array}{l}\text { R } \\
0\end{array}$ \\
\hline $\begin{array}{l}\frac{5}{\delta} \\
\text { ஸे }\end{array}$ & $\begin{array}{l}\hat{\mathscr{O}} \\
\stackrel{0}{0}\end{array}$ & $\stackrel{N}{\circ}$ & \& & $\stackrel{g}{\stackrel{g}{\leftarrow}}$ & $\begin{array}{l}\mathscr{L} \\
\infty \\
0 \\
0 \\
0\end{array}$ & $\begin{array}{l}\text { S̊ } \\
\stackrel{\circ}{\circ}\end{array}$ & $\begin{array}{l}0 \\
\stackrel{0}{\circ} \\
\stackrel{-}{2}\end{array}$ & 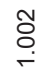 & 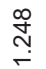 & $\underset{r}{\stackrel{\circ}{\circ}}$ & ঃ & \& & ஜ্ণ \\
\hline 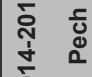 & 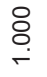 & 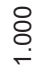 & 움 & \& & 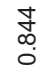 & $\begin{array}{l}\text { ֶू } \\
\text { ભ̆ } \\
0\end{array}$ & চ̋ & $\begin{array}{l}\stackrel{2}{0} \\
0 \\
0\end{array}$ & $\stackrel{\widehat{o}}{\circ}$ & $\stackrel{8}{\circ}$ & $\stackrel{8}{\circ}$ & \& & 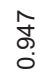 \\
\hline $\begin{array}{l}\overline{0} \\
\overline{0} \\
\stackrel{\Xi}{-1}\end{array}$ & $\begin{array}{l}\bar{\Sigma} \\
\text { ì }\end{array}$ & $\stackrel{\text { Oे }}{\leftarrow}$ & $\begin{array}{l}\stackrel{2}{R} \\
\hat{6} \\
0\end{array}$ & $\begin{array}{l}\infty \\
\infty \\
0 \\
0\end{array}$ & 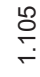 & $\begin{array}{l}\text { స్ } \\
0 \\
0\end{array}$ & $\begin{array}{l}0 \\
\text { L } \\
\infty \\
0\end{array}$ & 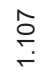 & 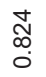 & $\begin{array}{l}0 \\
0 \\
0 \\
0 \\
0\end{array}$ & $\begin{array}{l}\hat{0} \\
\stackrel{0}{0}\end{array}$ & 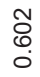 & $\begin{array}{l}\hat{0} \\
\& \\
0 \\
0\end{array}$ \\
\hline $\begin{array}{l}\text { 怘 } \\
\text { 壱 }\end{array}$ & $\begin{array}{l}\hat{\mathscr{o}} \\
\text { g. }\end{array}$ & $\stackrel{N}{\circ}$ & \& & $\stackrel{g}{\stackrel{g}{\leftarrow}}$ & $\begin{array}{l}\bar{\infty} \\
\infty \\
0\end{array}$ & ڤ̊ & $\stackrel{ }{\stackrel{5}{ }}$ & $\begin{array}{l}0 \\
0 \\
0 \\
0\end{array}$ & $\stackrel{\text { N̦ }}{\sim}$ & $\stackrel{8}{\circ}$ & $\stackrel{8}{\circ}$ & $\stackrel{\circ}{\circ}$ & 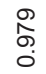 \\
\hline$\sum_{\Delta}^{\infty}$ & $\stackrel{\square}{\Delta}$ & 홈 & 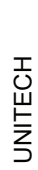 & 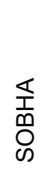 & 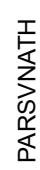 & 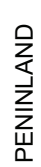 & 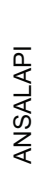 & $\frac{0}{\frac{1}{\alpha}}$ & $\begin{array}{l}\bar{z} \\
\frac{\alpha}{s} \\
s \\
د \\
\frac{2}{\omega} \\
0\end{array}$ & 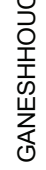 & 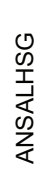 & $\frac{1}{3}$ & $\begin{array}{l}\stackrel{\complement}{\varpi} \\
\sum^{\infty}\end{array}$ \\
\hline
\end{tabular}




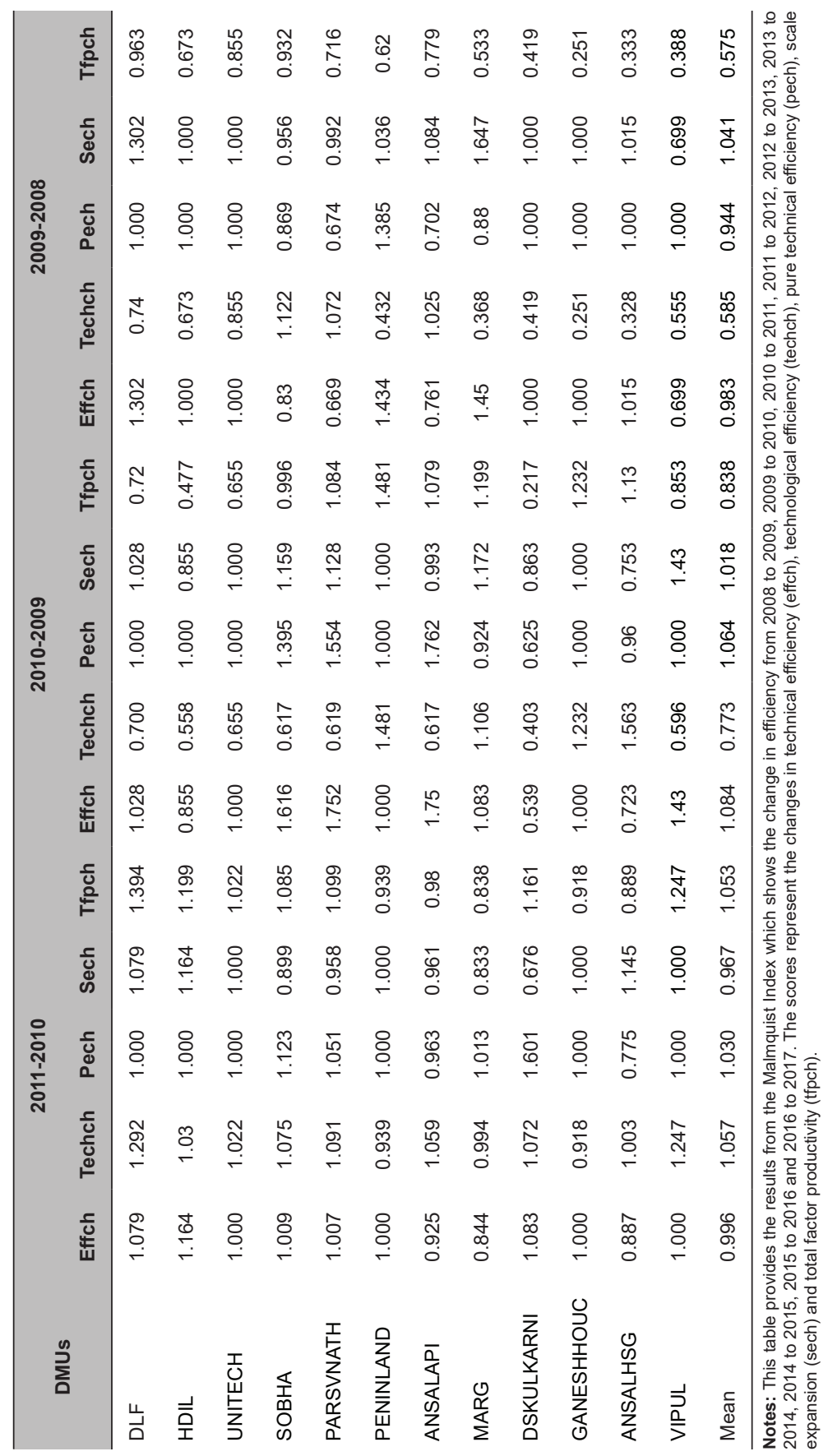


Overall from 2014 to 2015, the average technical efficiency of the firms improved, but on an average there was technological regress, which resulted in a decline of 7.9 per cent in the mean productivity of the firms during this period.

From 2013 to 2014, 3 firms (HDIL, Sobha and DS Kulkarni) showed improved performance. For HDIL, the improvement in productivity was due to improvements in both technological efficiency and technical efficiency. However, Sobha and DS Kulkarni experienced a slight deterioration, although it gained technical efficiency.

Unitech, Ganesh housing, Ansal housing and Vipul saw no change in technical efficiency, but suffered from technological regress, which resulted in overall productivity decline. Parsvnath and Marg showed improved technological change, but due to technical inefficiency their total productivity suffered.

Throughout 2012-2013, only 2 firms (DLF and Ganesh Housing) had productivity growth. The technological improvement was the main reason for the improved productivity of these two firms, as their technical efficiency remained same. The remaining firms suffered from productivity decline. The regress in productivity of 10 out of 12 firms was mostly due to technological deterioration.

All the firms except two (HDIL and Parsvnath) showed technological deterioration during 2011-12. Four firms (Hdil, Marg, DS Kulkarni and Ansal housing) showed improvement in technical efficiency. Overall there was 2.4 per cent improvement in technical efficiency in terms of annual mean, but due to technological regress, the annual mean productivity showed a decline of 12.7 per cent.

The best performance occurred during 2010 to 2011 when 7 firms (Dlf, HDIL, Unitech, Sobha, Parsvnath, DS Kulkarni and Vipul) experienced productivity growth. This improvement in productivity can be credited to technological change ( 9 firms showed technological improvement during this period). Overall from 2010-2011, the technological efficiency of the firms improved, which resulted in a rise of 5.4 per cent in the mean productivity of DMUs during this period. 
During 2009 to 2010, 6 firms (PARSVNATH, PENINLAND, ANSALAPI, MARG, GANESHHOUC and ANSALHSG) showed positive productivity. The improvement in productivity was because of both technological improvement and technical efficiency. Overall the mean technical efficiency showed a rise of 8.4 per cent, which came from a 6.4 per cent rise in input utilization and 1.8 per cent rise in scale expansion. UNITECH, PENINLAND and GANESHHOUC remained same on technical efficiency during this period.

During 2008 to 2009 , not even a single firm experienced productivity growth. The worst performance of firms occurred in this period, although 4 firms (DLF, Peninsula Land, Marg and Ansal housing) showed technical efficiency during this period. The regress in productivity can be attributed to both technological deterioration and technical inefficiency ( 9 firms showed technological regress and 8 firms showed efficiency decline). However, 7 firms showed same pure technical efficiency, whereas Peninsula Land showed increase in this component. Overall, mean productivity suffered a major decline of 42.5 per cent; technological deterioration was the main cause for this major decline.

Table 6: Summary of Malmquist Index Results

\begin{tabular}{|c|c|c|c|c|c|c|c|}
\hline & Year & $\begin{array}{l}\text { Productivity } \\
\text { growth }\end{array}$ & $\begin{array}{l}\text { Productivity } \\
\text { regress }\end{array}$ & $\begin{array}{l}\text { Technological } \\
\text { improvement }\end{array}$ & $\begin{array}{l}\text { Technological } \\
\text { deterioration }\end{array}$ & $\begin{array}{c}\text { Efficiency } \\
\text { improvement }\end{array}$ & $\begin{array}{l}\text { Efficiency } \\
\text { decline }\end{array}$ \\
\hline 2 & 2008-09 & 0 & 12 & 3 & 9 & 4 & 8 \\
\hline 3 & $2009-10$ & 6 & 6 & 4 & 8 & 6 & 6 \\
\hline 4 & $2010-11$ & 7 & 5 & 9 & 3 & 5 & 7 \\
\hline 5 & $2011-12$ & 2 & 10 & 2 & 10 & 4 & 8 \\
\hline 6 & $2012-13$ & 2 & 10 & 2 & 10 & 4 & 8 \\
\hline 7 & 2013-14 & 3 & 9 & 3 & 9 & 4 & 8 \\
\hline 8 & $2014-15$ & 5 & 7 & 1 & 11 & 4 & 8 \\
\hline 9 & $2015-16$ & 6 & 6 & 5 & 7 & 2 & 10 \\
\hline 10 & $2016-17$ & 3 & 9 & 2 & 10 & 3 & 9 \\
\hline
\end{tabular}

Notes: This table represents the number of firms from the sample which showed an increase or decrease in productivity, the number of firms which showed technological improvement or deterioration and the number of firms that showed the efficiency improvement or decline. 
As shown in Table 6, the Malmquist results summary directs that the number of firms with productivity growth was nil in the second year of sample in spite of efficiency increase in 4 firms. Productivity growth increased during the third year, which could be attributed to efficiency improvement. Productivity further increased during the fourth year, the growth in productivity was mostly because of technological improvement (9 firms out of 12 showed technological improvement). The number of firms with productivity growth decreased during fifth, sixth and seventh years of the sample. The regress in productivity growth during these years can be attributed to both technological deterioration and efficiency decline. It showed a slight improvement during the eighth and ninth year of the sample, 5 firms in the eighth (2014 to 2015) and 6 firms in ninth year (2015 to 2016) showed productivity growth. It further decreased in the tenth year, where 9 out of 12 firms showed productivity regress and this could be associated with both technological regress and technical efficiency decline during the same period (10 firms showed technological deterioration and 9 firms showed technical efficiency decline). The best performance in the context of productivity growth was in the fourth year (2010-11), when 7 out of 12 firms experienced a growth in productivity.

\section{CONCLUSION}

During the overall study period, most of the housing companies suffered from scale inefficiencies. Companies that were efficient in VRS terms (efficient input utilization) had inconsistencies from the efficient frontier due to scale inefficiencies. However, annual averages concluded that both pure technical inefficiency and scale inefficiencies contributed to the technical inefficiency of the housing companies. These findings suggest that there is a need for both better utilization of resources and scale expansion. Only one firm was consistently efficient for all the ten years (Ganesh Housing). When comparing annual averages, the study found that technical efficiency of housing companies was not on the efficient frontier, however average efficiency was near to the efficient frontier for the whole study period.

Based on the findings of the Malmquist Productivity Index, productivity growth occurred only during 2010-11 (5.4 per cent) and in rest of the years; it showed small annual improvements despite the relative technical 
efficiency improvement. It can be attributed to technological deterioration. Technological improvements can be achieved by proper input utilization and scale expansion. Therefore, the performance of housing companies can be improved through improvements in technological efficiency as it was the main reason for the poor productivity growth during the study period.

\section{REFERENCES}

Ahmed, A. A., \& Mohamad, A. (2016). Data envelopment analysis of efficiency of real estate investment trusts in Singapore. International Journal of Law and Management, 59(6), 826-838.

Anderson, R. I., Brockman, C. M., Giannikos, C., \& McLeod, R. W. (2004). A non-parametric examination of real estate mutual fund efficiency. International Journal of Business and Economics, 3(3), 225-238.

Charnes, A., Cooper, W. W., \& Rhodes, E. (1978). Measuring the efficiency of decision making units. European Journal of Operation Research, 2(6), 429-444.

Chen, Q., \& Li, F. (2017). Empirical analysis on efficiency of listed real estate companies in China by DEA. Ibusiness, 9, 49-59.

Chiu, C. Y., \& Wang, M. W. (2011). An integrated DEA based model to measuring financial performance of construction companies. WSEAS Transaction on Business and Economics, 1(8), 1-15.

Grimes, Jr., \& Orville, F. (1976). Housing for low income urban families. Economics Policy in the Developing World, IBRD Research Publication. Baltimore: Te Johns Hopkins University Press.

Roy, D., \& Kohli, B. (2016). Measuring the technical efficiency of Indian real estate sector through data envelopment analysis. International Journal of Applied Business and Economic Research, 14(14), 21-28.

Sepehrdoust, H. (2011). Efficiency measurement of housing sector using DEA model. International Conference on Economics and Finance Research, 4, 325-329. 
Soetanto, T. S., \& Fun, L. P. (2014). Performance evaluation of property and real estate companies listed on Indonesia Stock exchange using data envelopment analysis. Journal of Management and Entrepreneurship, 16(2), 121-130.

The Economic Times Wealth. (2018). Indian realty sector market to $\$ 180$ billion Retrieved from https://economictimes.indiatimes.com/weal th/personal-finance-news/indian-realty-sector-market-to-reach-180billion/articleshow/63301570.cms?from $=\mathrm{mdr}$

Zheng, X., Chau, K. W., \& Hui, E. C. M. (2011). Efficiency assessment of listed real estate companies: An empirical study of China. International Journal of Strategic Property Management, 15(2), 91-104. 